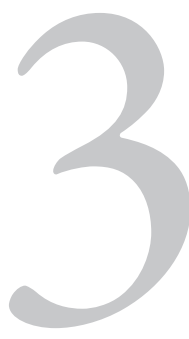

\title{
TRIP GENERATION RATES AND MOBILITY PATTERNS IN GATED RESIDENTIAL COMMUNITIES IN CÓRDOBA, ARGENTINA
}

\author{
TASAS DE GENERACION DE VIAJES \\ Y PATRONES DE MOVILIDAD EN \\ BARRIOS CERRADOS DE USO \\ RESIDENCIAL EN CORDOBA, \\ ARGENTINA
}

\author{
Alicia Riera ${ }^{1}$ \\ Carlos María Lucca ${ }^{2}$ \\ Julia Brusa ${ }^{3}$ \\ Claudio Falavigna ${ }^{4}$ \\ Héctor Taborda ${ }^{5}$ \\ Recibido: 22/04/2016 \\ Aceptado: 19/10/2016
}

\section{A B S T R A C T}

Trip generation rates in eight gated residential communities with different location built environments, street connectivity and transit service availability, show the influence of these variables on mobility patterns. Classified vehicle entry and exit counts at each site's gates were performed, including private car, taxi, motorcycle, school van, walk, bicycle and truck, while passengers were registered for occupancy rate estimation. Car trip generation rates per residential unit in those communities located in low density areas with little street connectivity and limited access to transit services, were three times greater than car trip rates in communities placed in denser areas with better street connectivity and available transit services. Private car ridership in isolated communities was over $70 \%$, while riding transit, walking and biking were less frequent.

1. Instituto de Investigación y Formación en Administración Pública - Universidad Nacional de Córdoba, Argentina. Correo: rieraalicia@gmail.com

2. Instituto de Investigación y Formación en Administración Pública - Universidad Nacional de Córdoba, Argentina. Correo: clucca2009@gmail.com

3. Instituto de Investigación y Formación en Administración Pública - Universidad Nacional de Córdoba, Argentina. Correo: arqbrusa@gmail.com

4. Instituto de Investigación y Formación en Administración Pública - Universidad Nacional de Córdoba, Argentina. Correo: cfalavigna@unc.edu.ar

5. Instituto de Investigación y Formación en Administración Pública - Universidad Nacional de Córdoba, Argentina. Correo: hectortaborda@hotmail.com 


\section{KE Y W O R D S}

Trip Generation - Built Environment - Gated Communities - Mobility Patterns - Residential Land Use.

\section{R E S U M E N}

Las tasas de generación de viajes correspondientes a ocho barrios cerrados de uso residencial, caracterizados por diferentes contextos del ambiente construido, conectividad vial y acceso al transporte público, muestran como estos atributos inciden sobre los patrones de movilidad. Se realizaron conteos clasificados de vehículos en los portones de ingreso y egreso de las urbanizaciones, incluyendo automóviles particulares, taxis, motocicletas, transporte escolar, personas a pie, bicicletas y camiones, además de contabilizar los pasajeros para estimar tasas de ocupación. La generación de viajes en automóvil particular por unidad residencial en urbanizaciones localizadas en áreas de baja densidad, con reducida conectividad vial y acceso limitado al transporte público, resultó tres veces mayor a la generación de viajes en urbanizaciones localizadas en áreas de mayor densidad, con mayor conectividad vial y disponibilidad de transporte público. En urbanizaciones aisladas, la participación modal del auto particular fue mayor al 70\%, mientras que el uso del transporte público, la caminata y la bicicleta resultó menos frecuente.

\section{PA L A B A S C L A V E}

Generación de Viajes - Ambiente Construido - Barrios Cerrados - Patrones de Movilidad - Uso Residencial

\section{I N T R O D U C T I O N}

A continuous socioeconomic segregation process is taking place in Latin American cities promoting urban space fragmentation, changing the structure of daily activities and people's mobility requirements (Borsdorf and Hidalgo, 2009). In the city of Cordoba this fragmentation process began in the 1990s decade along with the installation of large-sized residential premises, gated community ${ }^{6}$ type within large area lots, furnished with services and comfort amenities aimed at top income classes. Currently, real estate market offers a wide variety of possibilities targeted not only for high income groups but also for the middle class segment. These alternatives are mostly residential communities with smaller lots, three or more story buildings called "casonas" and high-rise buildings commonly known 
as "torres" (towers), all of them with fenced perimeters, private security and controlled entrances. By the year 2006, gated communities summed up to 52 housing developments over 1,500 hectares, roughly $2.6 \%$ of Cordoba city's total surface (Belloti, 2006).

Low density housing developments encourage car ridership increasing road infrastructure demand along with a negative impact on resource distribution. At the same time, extremely low public transportation demand levels registered for these locations have a negative incidence on quality standards leading to unsatisfactory levels of service. This situation persuades travelers against using transit, supporting a circular and cumulative feedback process that sponsors dependence on private motorized transportation. In this way, cars consume urban space at the expense of other transportation modes, hampering citizens' use of city assets (parks and squares; education and health services; sports, recreational and cultural premises) and placing limitations on certain population groups regarding their "right to the city".

From a public policies' perspective, understanding urban issues nature and dynamics is essential to accomplish appropriate policy design. According to Dunn (2007), many public policies fail because they have a tendency to propose the best solution for the wrong problem, which in terms of problem structuration in public policy analysis is known as a Type III error. For this reason, analyzing the articulation between mobility demand and land use patterns -in this particular case research performed in eight gated communities- provides data for a better understanding of this relationship, improving mobility public policies. Accelerated urbanization processes in Latin American cities (United Nations, 2015) and the lack of quantitative information regarding urban mobility patterns evolution, have prevented local governments from planning ahead, being deprived of tools for project appraisal and resulting externality mitigation. This issue has been a constant for countries within the region and for developing countries from other continents as well.

Local government urban planning departments in coordination with traffic and transit agencies are responsible for maintaining adequate land use distribution patterns and for performing residential development projects impact appraisal. Data availability representative of local conditions would ease such process, so the output of this piece of research would provide a valuable input for mitigation requirement assessment, warranting acceptable levels of equity. 


\section{TERR I T O R I A L F R A M E W O R K}

The study case belongs to the city of Cordoba, capital of the homonymous province placed in the central region of Argentina. Its centralized layout where plain areas and soft grades merge, runs from east to northeast along both margins of the Suquia River through the municipal administrative limits, a 24 kilometer square with a total area of 576 square kilometers. Besides being the second biggest city in Argentina after Buenos Aires, it is an important cultural, financial, economic and educational center. According to the last National Population and Housing Census ${ }^{7}$ the capital city had 1,330,023 inhabitants while the metropolitan area's population added around 377,000 inhabitants. Population relative growth rate between 2001 and 2010 census was 3.5\% while neighboring municipalities grew up to $30 \%$, implying a strong migration process towards towns close to the capital city. From a socioeconomic standpoint, in the province of Cordoba, poverty level estimation reached $26.8 \%$ for December 2013 (Caggia, 2014). Meanwhile, reported murder rate per ten thousand inhabitants for the city of Cordoba was 0.58 in 2012, increasing to 0.64 in 2013 (Observatorio Urbano Córdoba, 2014), with no police inaccessible areas so far. A 0.61 rate was reported for the Autonomous City of Buenos Aires. These figures are the lowest among reported rates for the region since in 2013 Brazil, Chile, Colombia and Uruguay showed respectively, murder rates per ten thousand inhabitant of 2.65, 0.31, 3.18 and 0.77 (Observatorio de Seguridad Ciudadana, 2016).

In 2015, Cordoba city's public transport system had a fleet of 801 buses and 49 trolleybuses with an annual ridership of 179,103,947 and a passenger kilometer rate of 3.11 [pas $/ \mathrm{km}]^{8}$. The system has acceptable headways but slow commercial speed. In general terms, urban service is characterized by good coverage and accessibility regarding walking distances, but very low performance during rush hours. The public transport system is under zonal concession regime and there are currently three private operators. Fare structure is composed by a regular fare, combined services fare and discounts for students, elderly, low income formal workers and persons with disabilities.

Urban structure evolution during the last period of the twentieth century was the result of a unbalanced renovation process which generated fragmentation and abandoned areas along the railway network together with

7. Censo Nacional de Población y Vivienda 2010

8. Source: www.cordoba.gob.ar 
character and identity loss of pericentral traditional neighborhoods, as well as their transformation in terms of their social and urban significance. The main morphological features of this dispersion and fragmentation process were: a concatenated generation of new ways of expansion by the establishment of gated communities that have no connection with urban public space; social polarization, residential segregation and fragmentation of the urban structure. In addition, a territorial segregation process which is also related with the economic value of land, was the outcome of suburbanization and multiple centralization. The city shows a northwest growth tendency which is fostered by an excellent foundation ground in that sector, mostly sand and rock, while clay soils are found in the northern and southern areas of the city. The natural scenery of the environment is another distinct factor of the northwest with hectares of "desired for" land where gated communities are progressively establishing and claiming for infrastructure. (Colautti, 2013)

The previous statements explain some of the reasons why, since the beginning of the 1990s decade, Cordoba city's urban growth process was marked by an increasing gated community real estate market mostly located along the periphery of the urban area as well as in several metropolitan area towns. Although a big proportion of these urbanizations developed in the northwest area, this housing typology is found in other locations, mainly in the southern area of the city. At the same time, social housing developments for lower income groups, built with either local government or cooperative funds, have settled near or outside the urban border as well. This process led to an expanded type of land use pattern that encouraged private car use and increased transit operation costs (Marengo \& Elorza, 2014; Peralta \& Liborio, 2014; Marengo, 2002).

Gated communities, which are locally identified as "countries", appear in response to high income class demands for a better quality of life. Initially, this type of urbanizations grew in absence of a regulatory framework, until Ordinance Number $8606 / 91^{9}$ was issued and modified by $10760 / 2004$, more than a decade later. This regulations establish requirements such as minimum lot areas, minimum percentage of common use areas, controlled access and an incredibly brief statement regarding environmental and urban impact provisions.

Tecco (2014) states that urban growth models influence citizens' mobility requirements. The city of Cordoba is lacking an urban plan that takes

9. Ordinance Number 8606/91 called Urbanizaciones Residenciales Especiales 
mobility into account as a significant variable regarding spatial organization, thus allowing urban agglomeration sprawl. This compels authorities to adequate transport services and to provide the infrastructure this requires, in response to previous interventions performed by the private sector. Functional zoning and residential segregation are likely to increase population mobility requirements; within asymmetric contexts of resources and capacities this can negatively affect different social segments regarding equality of opportunities to exercise their right to the city.

\section{TRIP GENERATION RATES ESTIMATION STATE OF THE ART}

The most relevant reference at the international level linked to trip generation rate analysis, is the Institute of Transportation Engineers (ITE) publication ${ }^{10}$ which assembles the outcomes of research carried out in the United States of America since the 1950s decade and more systematically since the 1970s. Research performed by ITE most commonly refers to trips that are generated by private vehicles, i.e. cars, during a certain period, daily or during peak hours, besides directional distribution distinguishing entrance and exit traffic flows. Collected data is employed for the definition of simple lineal regression equations, trip generation rate weighted averages and measures of correlation. Much of this data has been obtained in suburban areas with plenty of free parking space, low density, individual land uses and minimum transit services which has resulted in rate overestimation, whenever the former conditions are not met. The manual is periodically updated by the addition of data points and the introduction of new land uses. The latest edition contains data from up to 6000 sites for 172 land uses. Three trip estimation methods are considered: a) By means of graphs that show number of trips versus independent variable values; this method is applicable when there is sufficient data; b) Computing trip generation rate weighted mean, i.e. number of trips weighted by independent variable unit and c) By estimating a regression equation linking number of trips with an independent variable. 
Local studies are required for multiple reasons such as Trip Generation rate or equation validation, land uses not included in the manual or whenever there is a requirement for rates that reflect unique local conditions. In the United Sates, the Trip Generation Manual is a must have for transportation professionals conducting site impact studies, determining on-site circulation patterns, performing access management studies, determining traffic signal timing, and conducting environmental assessment. In spite of the publication's reputation and data volume provided by this tool, rates defined by ITE are not applicable to Latin American cities, mainly due to differences in mobility behavior patterns. On the other hand, ITE only reports car trips, leaving aside other transport modes. At the local level these alternative modes show shares which not only justify but call for their inclusion in trip generation studies.

In Latin America we can highlight studies coordinated by the Rede Iberoamericana de Polos Geradores de Viagens ${ }^{11}$ (Portugal, 2012) which aim to develop a regional trip generation database for different land use types. Within this framework Grieco and Portugal, (2010) conducted specific research in the Brazilian city of Niteroi analyzing two residential site types with different built environments. Counts were performed in a total of eleven condominiums, six of them High-Rise Apartment type (ITE code 222), located in a dense region with mixed uses and good transit provision. Other five condominiums, Single-Family Detached Housing type (ITE code 210) were located in a solely residential low density area with no transit service. Car trip rates per residential unit for vertical denser condominiums were 3.7 times lower than car rates observed for horizontal low density condominiums. At the same time, in comparison to values recommended by ITE (2012) for similar housing and built environment types, car trip generation rates were substantially lower. Walk trips were counted, which included walking to or from a transit stop. The weighted daily walk trip rate for vertical rise sites was 7.04 while single-family detached housing sites weighted daily rate was 1.35 , barely $19 \%$ of the former rate value.

Another relevant study case was performed in the city of Mérida, Venezuela (Quintero et al, 2011) In order to produce data that could be incorporated into the Rede Iberoamericana de Polos Geradores de Viagens network, car trip counts were carried out in four residential condominiums to produce rates related to attributes of these generators, obtaining regression equations, correlation coefficients, average generation rates and data graphs. 
Independent variables that showed the best correlations were number of apartments and number of parking spaces per residential site. The correlation coefficients obtained for the first variable ranged between 0.82 and 1.00 and for second between 0.63 and 0.92 for the different scenarios that were discussed. Residential land use car trip rates obtained in Merida were smaller than those recommended by ITE for similar land use types.

At the local level research has concentrated on large trip generation centers such as shopping centers, hospitals, and university campus while residential trip generation is only just being addressed in spite of the fact that households concentrate around $80 \%$ of the origins and destinations of all trips (Ortúzar and Willumsen, 2011), reason enough to highlight the value of local residential trip data collection and analysis. Academic trip generation research background in the city of Cordoba has focused on malls (Galarraga et al, 2007), health centers (Albrieu et al, 2011) and educational sites (Herz et al, 2007). Galarraga et al, 2007, conducted a trip generation study in hypermarkets analyzing seven cases belonging to three different supply chain companies. They performed entry and exit counts in order to measure car and taxi trips, besides vehicle occupancy. Total built area, total sales area and number of check-out places were considered for the independent variables. Sales area proved to be a better explanatory variable than total area while local rates were around a third (33\%) of those reported by ITE.

Herz et al, (2007) studied trip generation in university centers in Cordoba, Argentina, performing counts in eleven educational centers, ten of them part of the National University of Cordoba while number eleven was a private university. Students and teachers were surveyed in every entry, registering number of trips, transport mode and trip origin. Student population, total classroom area and over-all area were chosen as probable independent variables. Findings showed that the number of enrolled students was the best explanatory variable. The study revealed that car use in universities located in high density areas with good transit provision, was far lower if compared with university centers in the United States.

Local research on residential land use trip generation is absent except for recent thesis work recorded by Bordese and Galarraga (2015) ${ }^{12}$. The latter studies nine urbanizations in the city of Cordoba, comprising three residential types within different built environments. Car and walk trip generation rates are obtained, showing significant differences between both built

12. This case study is very much alike the research described in this article for which reason it should be made clear that the projects were contemporary and independently designed. 
environments as well as with ITE rates for analogous residential types. On this basis the authors state the need for local data collection. The case presented in this paper makes a further contribution by comparing trip generation rates in eight residential gated communities with different location, built environment, street connectivity and transit services, aiming to prove the influence these attributes wield on mobility patterns.

Chile's government transportation authorities (SECTRA, 2011) in the context of their Highway and Transit Program, carries on a work course intended to build a vehicular trip generation database for residential and non-residential projects in the country's main cities. Although impact analysis is required for the approval of building or urbanization projects, objective and common technical criteria is lacking for trip rate estimation. When based on an extensive background with a variety of trip generation rates associated to real estate projects in different cities and of diverse types, Urban Transportation System Impact Studies development and approval processes are expected to be more efficient. Among these research efforts we can quote "Generation and Attraction Rates for Residential and Non-residential Projects in the South Region of the Country" and "Generation and Attraction Rates for Residential and Non-residential Projects in the Central Region of the Country". Both studies performed vehicular access and exit counts in different types of sites located in various cities: malls, shopping centers, bus terminals, parking sites, condominiums, towers, etc. Trip generation rates were associated to units specifically related to each land use type, for example sales area in the case of malls, number of residential units for condominiums and towers and number of parking lots in the case of parking sites.

Further references can be quoted regarding trip generation in the city of Cordoba, but with a different methodological approach. Riera, (2012) estimated walk and bicycle trip generation home based models while Riera and Galarraga, (2012) developed home based walk models including built environment variables as well. Riera and Brusa (2012) estimated motorized trip choice models that included household and built environment variables. Brusa et al (2013) formulated a multinomial logistic modal choice model. In every case results showed that built environment variables such as residential density, land use diversity and network connectivity, in addition to socioeconomic factors, influence individual's decision regarding travel by car, transit or non-motorized modes. 


\section{METH O D O L O G I A L F R A E W O R K}

Two clearly different types of exclusive residential land use, gated community type, were addressed. We call "Type A" those communities with three or more story buildings -middle density- located within mixed use environments where most services are available, besides being provided with a well connected adjacent street network and accessible transit services. Several sites were taken into consideration and assessed to see whether they fulfilled the previous conditions. Casonas del Norte, Casonas del Sur, Casonas del Parque and La Huertilla urbanizations were selected from a list of possible sites. On the other hand, "Type B", refers to those communities with separate single family units in low density developments distant from basic services, limited street connectivity and scarce or no access to transit services. In this case La Reserva, Fortin del Pozo, Jardin Claret and Barrancas Sur urbanizations proved to be adequate. In all cases the greatest difficulty was to obtain community administration approval to carry on with counts, given the importance attached to security issues. With regard to categories defined by ITE (2012), Type A housing sites match code 232 (High-Rise Residential Condominium/Townhouse) while Type B sites agree with code 210 (Single Family Detached Housing).

Four housing developments were surveyed for each urbanization type, which were selected in compliance with the following criteria: a) dwellers of both location types show a similar socioeconomic level appraised in ter$\mathrm{ms}$ of common expenditures values, real estate prices and average rental estimates; b) all housing groups are residential use only, multiple use sites are avoided; c) total units per housing should not be less than 40 dwellings; d) access is controlled in order to allow entrance and exit flow counts; e) occupancy rates should be at least $85 \%$; f) developments must have a minimum two years holding its present use. ITE (2012) requirements were taken into account and complied, as far as possible, in order to perform a comparative analysis of field work outcomes and findings. Furthermore, not complying the established criteria would produce more general figures not representative of the studied typologies, thus limiting model and trip rate application for future gated community traffic impact appraisal.

Counts were performed during typical labor days, rescheduling field work in case of rainfall, transport strikes, or any other kind of events that could alter usual behavior patterns. Counts were carried out manually, during a fourteen hour continuous period, between 7:00 am and 9:00 pm. The previous time slot is justified since it concentrates most routine activities in coincidence with traffic peak periods observed in access roads. 
Entries and exits were registered at the sites' gates recording data on specially designed sheets, on a fifteen minute interval basis. Counts were performed classifying transport modes as follows: private car, taxi, motorcycle, school van, walk, bicycle and truck. The total number of persons on board, including the driver, was registered for occupancy rate estimation.

Regarding independent variables for trip rate computation, the total number of residential units was adequate for both urbanization types. The number of parking lots was suitable as well, although it was applicable for “Type A" urbanizations only, since parking in "Type B" dwellings depends on the available space in each residential unit.

Mobility may be linked to several other household variables such as average number of household members, urbanization dwellers' mean age, residential unit average area or car ownership. Examining these associations was not possible since this data, considered as private information, was not provided for by any of the selected sites' administrators. On the other hand, the previous independent variables are not suitable for performing new urbanization impact analysis because they are obviously not defined during project stages, unlike site number of residential and parking units. Moreover, being short of information about the variables above is not relevant to this piece of research, neither does it modify its analysis and conclusions. However, their availability would have made a contribution for assessing socioeconomic profiles impact on trip generation rates.

\section{RE S I D E N T I A L G R O U P C H A R A C T R I Z A T I O N}

Table 1 summarizes a set of socioeconomic, urban and mobility transportation zone ${ }^{13}$ indicators associated to each development's zone location (see Figure 1). La Reserva, Jardín Claret, Fortín del Pozo and Barrancas del Sur (Type B) housings are placed in low population density areas, i.e. less than 1,500 inhabitants per square kilometer. The first two are located in the northwest area of the city, close to the northern section of Avenida de Circunvalacion, while the latter are close to the southern section of Circunvalacion, in the southern limit of the city. Residential land use share within these urbanizations' transportation zones ranges between $62 \%$ and $99 \%$. In every case

13. Transportation zones make reference to zonal division for the last travel survey performed in the city of Cordoba during the year 2009, which was reported by PTUMA (2011) Travel Survey. 
the sites' zones include a considerable amount of vacant land together with big lots containing important developments such as manufacturing companies, important sports fields and large exhibition grounds. Street network connectivity is low, represented by number of squares per hectare ranging between 0.1 and 0.55 , which is consistent with the previous land use type. It can be seen that the transportation zone where Fortin del Pozo is located contains industrial and rural land uses while in the case of La Reserva, zonal land use is residential only, including gated communities type developments and a natural reserve area. Regarding Jardin Claret, the zone comprises consolidated fairly mixed land use neighborhoods, heterogeneous socioeconomic levels between different residential sections, industrial areas and some vacant land. It is worth noticing that transportation zones where La Reserva and Fortin del Pozo are located, show the highest indicators concerning average family income, socioeconomic level and number of cars per household. Barrancas Sur and Casonas del Sur communities, on the other hand, are placed in middle density transportation zones, i.e. less than 3,500 inhabitants per square kilometer, which show intermediate street network connectivity (see Table 1). This means we are in the presence of consolidated square grid layout surroundings yet full of green spaces. Last, La Huertilla, Casonas del Norte and Casonas del Parque housings are located in middle density areas (less than 6,500 inhabitants per square kilometer) along with high street network connectivity design. The latter, as well as Casonas del Sur, are near the Central Area, close to several transit routes. In comparison with the first group of housings, the surrounding areas are denser (see Figure1).

Street network connectivity is considerably higher, ranging between 0.53 and 0.88 squares per hectare. Although no quantification of accessibility was carried out, it is worth noticing that Type A urbanizations provide greater access to city assets such as commercial, educational and health services, easy to get to by transit and in many cases on foot. 
FIGURE 1

POPULATION DENSITY AND STUDIED COMMUNITIES LOCATION

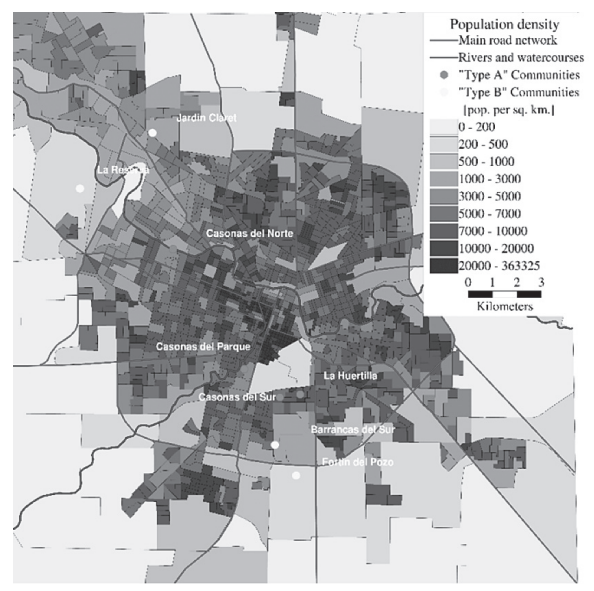

SOURCE: SELF-ELABORATION BASED ON INDEC INFORMATION.

\section{TABLE 1}

\section{COMMUNITIES ZONE CHARACTERIZATION BASED ON TRANSPORTATION ZONE LIMITS}

\begin{tabular}{|c|c|c|c|c|c|c|c|c|}
\hline \multirow[b]{2}{*}{ COMMUNITY NAME } & \multicolumn{4}{|c|}{ ties located in middle density areas) } & \multicolumn{4}{|c|}{ B (gated communities located in low density areas) } \\
\hline & LA HUERTILLA & $\begin{array}{l}\text { CASONAS } \\
\text { DEL SUR }\end{array}$ & $\begin{array}{c}\text { CASONAS } \\
\text { DEL PARQUE }\end{array}$ & $\begin{array}{l}\text { CASONAS } \\
\text { DEL NORTE }\end{array}$ & LARESERVA & $\begin{array}{l}\text { JARDIIN } \\
\text { CLARET }\end{array}$ & $\begin{array}{c}\text { FORTÍN } \\
\text { DEL POZO }\end{array}$ & $\begin{array}{l}\text { BARRANCAS } \\
\text { SUR }\end{array}$ \\
\hline TAZ1 number $^{1}$ & 56 & 14 & 12 & 36 & 32 & 38 & 52 & 15 \\
\hline Zone area [km2] & 4.28 & 4.62 & 2.15 & 4.16 & 26.00 & 16.59 & 27.41 & 6.38 \\
\hline Avg. Household income ${ }^{2}[\$$ Arg] & 2,686 & 3,622 & 2,452 & 3,717 & 6,120 & 3,009 & 8,394 & 2,948 \\
\hline Zonal population density [inhab./km2] & 6.242 & 3.384 & 6.187 & 5.293 & 201 & 1.049 & 209 & 3.238 \\
\hline Avg. INSE ${ }^{3}$ & 3.20 & 4.40 & 3.60 & 4.50 & 5.20 & 4.10 & 6.00 & 3.90 \\
\hline$\%$ Residential land use & $88 \%$ & $88 \%$ & $92 \%$ & $86 \%$ & $99 \%$ & $67 \%$ & $62 \%$ & $78 \%$ \\
\hline $\begin{array}{l}\text { Street network connectivity } \\
\text { [squares per hectare] }\end{array}$ & 0.84 & 0.53 & 0.75 & 0.88 & 0.27 & 0.30 & 0.10 & 0.55 \\
\hline Avg. Cars per household & 0.66 & 0.91 & 0.36 & 0.57 & 1.33 & 0.68 & 2.00 & 0.42 \\
\hline Avg. Inhabitants per household & 3.86 & 3.43 & 3.00 & 3.00 & 4.17 & 3.77 & 4.14 & 2.97 \\
\hline Trips per person (all cases) & 1.23 & 1.89 & 1.18 & 2.06 & 1.80 & 1.46 & 1.55 & 2.02 \\
\hline Trips per person (travelers only) & 2.08 & 2.36 & 2.11 & 2.96 & 2.37 & 2.12 & 2.25 & 2.77 \\
\hline
\end{tabular}

SOURCE: PREPARED BY AUTHORS, BASED ON CORDOBA HOUSEHOLD TRAVEL SURVEY DATA (PTUMA, 2011). NOTES:

1: TAZ TRANSPORT AREA ZONE BASED ON PTUMA (2011) TRAVEL SURVEY.

2: HOUSEHOLD INCOME VALUE SOURCE: CORDOBA'S HOUSEHOLD TRAVEL SURVEY (PTUMA, 2011) MODIFIED BY INDEC'S MEAN VALUES.

3: INSE SOCIOECONOMIC INDEX: INDIRECT MEASURE OF HOUSEHOLD SOCIOECONOMIC LEVEL BASED ON THE METHODOLOGY BY THE "ASOCIACIÓN ARGENTINA DE MARKETING". INSE WAS AVAILABLE IN PTUMA TRAVEL SURVEY DATABASE. INSE SOCIOECONOMIC LEVEL VALUES RANGE BETWEEN 1 (LOW) AND 6 (HIGH).

4: STREET NETWORK CONNECTIVITY: THE AMOUNT OF SQUARES PER HECTARE IS AN INDICATOR OF STREET CONNECTIVITY. 


\section{F I N D I N G S}

This section summarizes research outcomes, which are displayed in three subsections as follows: subsection 6.1 shows modal split related results of trips generated by each residential land use. Next, subsections 6.2 and 6.3 summarize car and walk trip rates by residential group. Finally, subsection 6.4 deals with private car trip time distribution.

\subsection{TRIP MODAL SPLIT}

Results presented in Table 2 show that in low density urbanizations located in the urban periphery, with little street network connectivity and limited access to transit (Type B), the private car has a major share in modal split. Thereby, for all four type B locations, car share averaged $77.3 \%$. At the same time, school transport share was three times the value found in type A communities while non-motorized modes share (walk and bicycle) was very low, around $10 \%$. In both cases walk trips may encompass transit trips since person targeted surveys would have been required in order to disaggregate this information. More taxi trips were generated by Type A urbanizations $(330 \%)$, probably because of lower car ownership rates and lower distances to the Central Area.

TABLE 2

\section{MODAL SPLIT BY COMMUNITY TYPE}

\begin{tabular}{|c|c|c|c|c|c|c|c|c|}
\hline & & \multicolumn{7}{|c|}{ Modal split [\%] ${ }^{1}$} \\
\hline & CARS & TAXI & MOTORCYCLE & $\begin{array}{c}\text { SCHOOL } \\
\text { TRANSPORT }\end{array}$ & WALK & BIKE & OTHERS & TOTAL \\
\hline Type A Communities & 59.8 & 6.3 & 2.7 & 1.8 & 25.3 & 4.0 & 0.1 & 100.0 \\
\hline Casonas del Sur & 56.3 & 9.6 & 1.8 & 1.3 & 30.3 & 0.5 & 0.1 & 100.0 \\
\hline Casonas del Parque & 65.3 & 7.9 & 4.4 & 5.2 & 15.9 & 1.0 & 0.3 & 100.0 \\
\hline La Huertilla & 46.7 & 2.3 & 2.3 & 0.0 & 34.5 & 14.2 & 0.0 & 100.0 \\
\hline Casonas del Norte & 70.7 & 5.5 & 2.3 & 0.6 & 20.6 & 0.3 & 0.0 & 100.0 \\
\hline Type B Communities & 77.3 & 1.9 & 3.4 & 5.5 & 9.9 & 1.2 & 0.7 & 100.0 \\
\hline Barrancas Sur & 71.3 & 1.9 & 1.7 & 6.0 & 17.0 & 1.4 & 0.7 & 100.0 \\
\hline Jardín Claret & 79.8 & 1.5 & 3.5 & 5.7 & 7.6 & 0.9 & 1.0 & 100.0 \\
\hline Fortín del Pozo & 80.9 & 2.4 & 5.1 & 4.6 & 5.1 & 1.4 & 0.5 & 100.0 \\
\hline La Reserva & 89.2 & 1.9 & 3.9 & 0.1 & 3.9 & 0.8 & 0.2 & 100.0 \\
\hline
\end{tabular}

NOTES:

1 TRIP DISTRIBUTION REFERS TO THE TOTAL NUMBER OF VEHICLE PASSENGERS (NOT TO VEHICLES).

- IN THE CASE OF CAR TRIPS, THE NUMBER OF OCCUPANTS ON EACH VEHICLE WAS RECORDED.

- TRANSIT SHARE IS NOT IDENTIFIED SINCE POTENTIAL TRANSIT RIDERS ENTER OR EXIT THE SITE ON FOOT.

SOURCE: PREPARED BY AUTHORS, BASED ON COUNTS DATA. 


\subsection{CAR TRIPS}

Table 3 reveals that Type $B$ urbanizations generate substantially more car trips per residential unit $(300 \%)$ than Type A locations. Meanwhile, Type A mean car trip rate per parking space is in most cases lower than mean car trip rate per residential unit. When comparing local trip generation rates with those obtained in the USA (ITE, 2012) it is noted that daily car trip rates per residential unit of low density urbanizations located within little street connectivity and limited transit access areas (Type B ), are similar to those in the USA (ITE code 210 Single Family Detached Housing). With regard to higher density urbanizations with better access to transit (Type A), car trip rates are lower than the ones observed in similar urbanizations in the USA (ITE code 232 High-Rise Residential Condominium/Townhouse).

TABLE 3

\section{CAR DAILY TRIPS AND TRIP GENERATION RATES}

\begin{tabular}{|c|c|c|c|c|c|c|c|c|c|}
\hline \multirow{2}{*}{ Type A urbanizations } & \multicolumn{3}{|c|}{ Number of daily ${ }^{\mathrm{a}}$ trips ${ }^{\mathrm{b}}$} & \multirow{2}{*}{$\begin{array}{c}\text { NUMBER OF } \\
\text { RESIDENTIAL } \\
\text { UNITS (RU) }\end{array}$} & \multirow{2}{*}{$\begin{array}{c}\text { ENTRY } \\
\text { RATERU }\end{array}$} & \multirow{2}{*}{$\begin{array}{c}\text { EXIT } \\
\text { RATERU }\end{array}$} & \multirow{2}{*}{$\begin{array}{c}\text { TOTAL } \\
\text { RATE RU }\end{array}$} & \multirow{2}{*}{$\begin{array}{l}\text { No OF PARKING } \\
\text { SPACES }(\text { (PS) }\end{array}$} & \multirow{2}{*}{$\begin{array}{c}\text { TOTAL RATE } \\
\text { PS }\end{array}$} \\
\hline & ENTRIES & EXITS & TOTAL & & & & & & \\
\hline Casonas del Sur & 272 & 315 & 587 & 230 & 1.18 & 1.37 & 2.55 & 253 & 2,32 \\
\hline Casonas del Parque & 182 & 198 & 380 & 98 & 1.86 & 2.02 & 3.88 & 100 & 3,80 \\
\hline La Huertilla & 153 & 184 & 337 & 80 & 1.91 & 2.30 & 4.21 & 48 & 7,02 \\
\hline Casonas del Norte & 422 & 463 & 885 & 253 & 1.67 & 1.83 & 3.50 & 270 & 3.28 \\
\hline \multicolumn{10}{|l|}{ Type B Urbanizations } \\
\hline Barrancas Sur & 223 & 224 & 447 & 45 & 4.96 & 4.98 & 9.93 & $n / d$ & $\mathrm{n} / \mathrm{d}$ \\
\hline Jardín Claret & 1228 & 1261 & 2489 & 250 & 4.91 & 5.04 & 9.96 & $n / d$ & $\mathrm{n} / \mathrm{d}$ \\
\hline Fortín del Pozo & 613 & 600 & 1213 & 108 & 5.68 & 5.56 & 11.23 & $n / d$ & $n / d$ \\
\hline La Reserva & 1176 & 1164 & 2340 & 250 & 4.70 & 4.66 & 9.36 & $\mathrm{n} / \mathrm{d}$ & $n / d$ \\
\hline \multicolumn{4}{|c|}{ Weighted mean Type A urbanizations } & 165.00 & & & 3.31 & 212.01 & 3.48 \\
\hline \multicolumn{4}{|c|}{ Standard deviation Type A urbanizations } & 88.85 & & & 0.72 & 110.53 & 2.04 \\
\hline \multicolumn{4}{|c|}{ Weighted mean Type B urbanizations } & 163.3 & & & 9.94 & - & - \\
\hline \multicolumn{4}{|c|}{ Standard deviation Type B urbanizations } & 103.4 & & & 0.79 & - & - \\
\hline
\end{tabular}

A) DAILY MOVEMENTS: COUNTS WERE UNDERTAKEN BETWEEN 7:00 AM AND 9:00 PM, PERIOD DURING WHICH MOST TRIPS TAKE PLACE.

B) A TRIP INVOLVES THE MOVEMENT OF A VEHICLE REGARDLESS OF ITS OCCUPANCY RATE.

C) CAR PARKING IN TYPE B URBANIZATIONS DEPENDS ON THE AVAILABLE SPACE IN EACH RESIDENTIAL UNIT, I.E. IT ISN'T PART OF THE URBAN PROJECT SO NO DATA IS AVAILABLE.

SOURCE: PREPARED BY AUTHORS, BASED ON COUNTS DATA 


\subsection{WALK TRIPS}

Walk trip rates are displayed in Table 4 below. These trips may be either a hundred percent walk or comprise walk trip stages before boarding and/ or after alighting another transport mode such as transit. Type A urbanization average walk trip rate is 1.9 times the average rate estimated for type B sites, showing a greater propensity to walk and ride transit in the former locations. Yet, walk trip rates for both location types are significantly lower than car trip rates, pointing out a very strong car dependency of gated community households.

TABLE 4

WALK DAILY TRIPS AND TRIP GENERATION RATES

\begin{tabular}{|c|c|c|c|c|c|c|c|c|c|}
\hline \multirow{2}{*}{ Type A urbanizations } & \multicolumn{3}{|c|}{ Number of daily walk trips } & \multirow{2}{*}{$\begin{array}{l}\text { NUMBER OF } \\
\text { RESIDENTIAL } \\
\text { UNITS (RU) }\end{array}$} & \multirow{2}{*}{$\begin{array}{l}\text { ENTRY } \\
\text { RATE RU }\end{array}$} & \multirow{2}{*}{$\begin{array}{c}\text { EXIT } \\
\text { RATE RU }\end{array}$} & \multirow{2}{*}{$\begin{array}{l}\text { TOTAL } \\
\text { RATE RU }\end{array}$} & \multirow{2}{*}{$\begin{array}{l}\text { № OF PARKING } \\
\text { SPACES (PS) }\end{array}$} & \multirow{2}{*}{$\begin{array}{c}\text { TOTAL RATE } \\
\text { PS }\end{array}$} \\
\hline & ENTRIES & EXITS & TOTAL & & & & & & \\
\hline Casonas del Sur & 154 & 261 & 415 & 230 & 0.67 & 1.13 & 1,80 & 253 & 1,64 \\
\hline Casonas del Parque & 59 & 64 & 123 & 98 & 0.60 & 0.65 & 1,26 & 100 & 1,23 \\
\hline La Huertilla & 182 & 155 & 337 & 80 & 2.28 & 1.94 & 4,21 & 48 & 7,02 \\
\hline Casonas del Norte & 182 & 163 & 345 & 253 & 0.72 & 0.64 & 1.36 & 270 & 1.28 \\
\hline \multicolumn{10}{|l|}{ Type B urbanizations } \\
\hline Barrancas Sur & 83 & 53 & 136 & 45 & 1.84 & 1.18 & 3,07 & $\mathrm{n} / \mathrm{d}$ & $\mathrm{n} / \mathrm{d}$ \\
\hline Jardín Claret & 153 & 139 & 292 & 250 & 0.61 & 0.56 & 1,17 & $n / d$ & $n / d$ \\
\hline Fortín del Pozo & 57 & 42 & 99 & 108 & 0.53 & 0.39 & 0,92 & $\mathrm{n} / \mathrm{d}$ & $n / d$ \\
\hline La Reserva & 79 & 39 & 118 & 250 & 0.32 & 0.16 & 0,47 & $\mathrm{n} / \mathrm{d}$ & $\mathrm{n} / \mathrm{d}$ \\
\hline \multicolumn{4}{|c|}{ Weighted mean Type A urbanizations } & 201.08 & & & 1.85 & & 2.09 \\
\hline \multicolumn{4}{|c|}{ Standard deviation Type A urbanizations } & 88.85 & & & 1.39 & & 2.83 \\
\hline \multicolumn{4}{|c|}{ Weighted mean Type B urbanizations } & 163.25 & & & 0.99 & - & - \\
\hline \multicolumn{4}{|c|}{ Standard deviation Type B urbanizations } & 103.42 & & & 1.12 & - & - \\
\hline
\end{tabular}

SOURCE: PREPARED BY AUTHORS, BASED ON COUNTS DATA

\subsection{TRIP TIME DISTRIBUTION}

Private car trip time distribution, including both entries and exits, is shown in Figure 2 and cross correlation coefficients are presented in Table 5. Similar distribution patterns applied to urbanizations of the same type. Clearly, type B urbanizations time series show similar patterns with high correlation (see Table 5). In these urbanizations a major demand peak was registered late in the afternoon and two softer peaks in the morning and at midday hours. Type A communities have a more disperse pattern which leads to a least correlation between time series (see Table 5). This type of urbanizations showed three very much alike distinct demand peaks, early in the morning, at midday and late in the afternoon. 
FIGURE 2

TRIP TIME DISTRIBUTION BY URBANIZATION TYPOLOGY
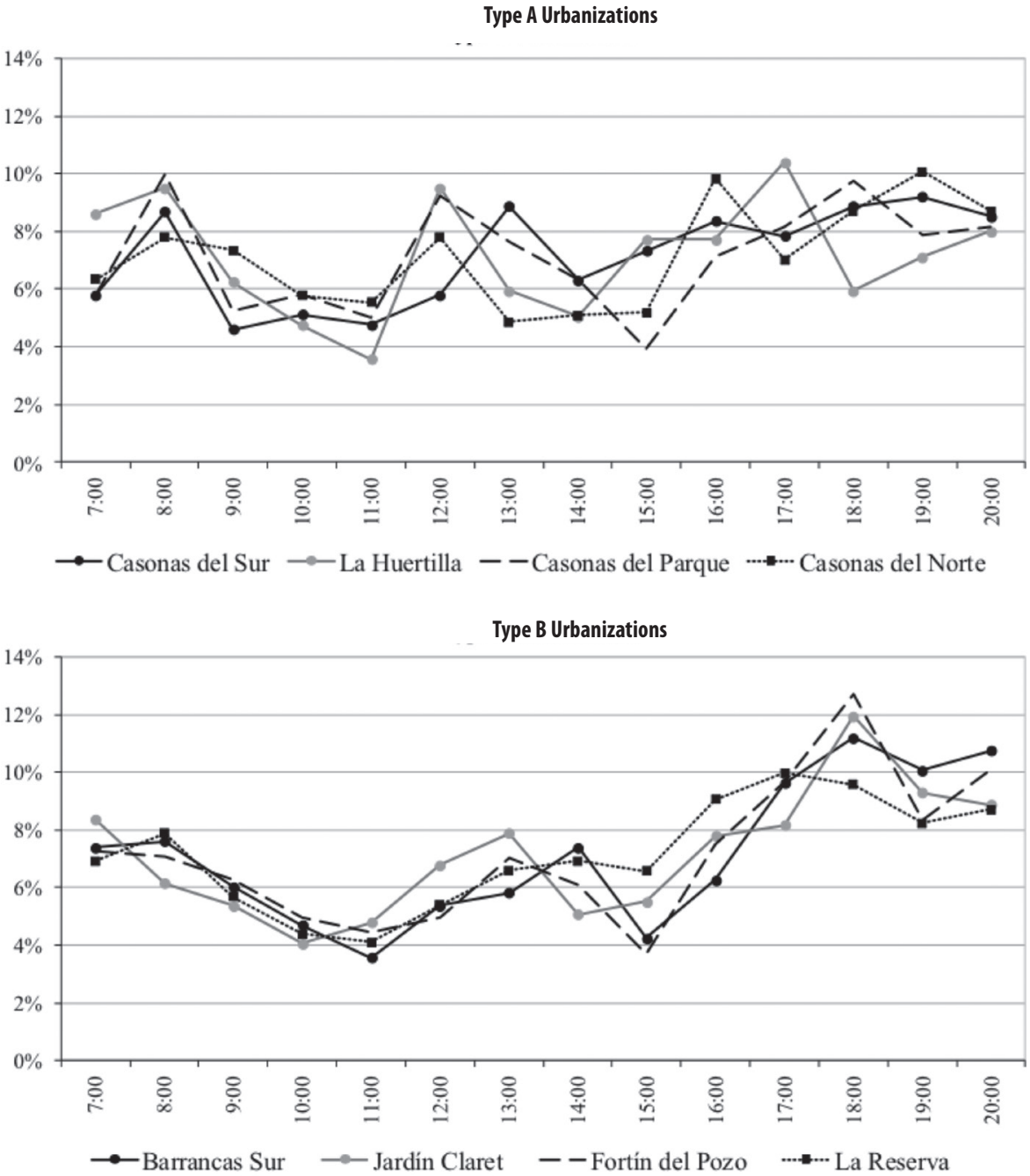

SOURCE: PREPARED BY AUTHORS, BASED ON COUNTS DATA 
TABLE 5

\section{TIME SERIES CORRELATION: CROSS CORRELATION COEFFICIENTS AT LAG O}

\begin{tabular}{|c|c|c|c|c|c|c|c|c|c|}
\hline & & \multicolumn{4}{|c|}{ Type A Urbanizations } & \multicolumn{4}{|c|}{ Type B Urbanizations } \\
\hline \multirow{5}{*}{ ฏ } & & $\begin{array}{l}\text { CASONAS } \\
\text { DEL SUR }\end{array}$ & $\begin{array}{c}\text { CASONAS } \\
\text { DEL PARQUE }\end{array}$ & LA HUERTILLA & $\begin{array}{l}\text { CASONAS } \\
\text { DEL NORTE }\end{array}$ & $\begin{array}{l}\text { BARRANCAS } \\
\text { SUR }\end{array}$ & $\begin{array}{l}\text { JARDÍN } \\
\text { CLARET }\end{array}$ & $\begin{array}{l}\text { FORTÍN } \\
\text { DEL POZO }\end{array}$ & LA RESERVA \\
\hline & Casonas del Sur & 1.00 & $0.617^{*}$ & 0.365 & 0.488 & $0.643^{*}$ & $0.696^{*}$ & $0.634^{*}$ & $0.796^{*}$ \\
\hline & Casonas del Parque & & 1.00 & 0.468 & $0.560^{*}$ & $0.636^{*}$ & $0.605^{*}$ & $0.646^{*}$ & $0.562^{*}$ \\
\hline & La Huertilla & & & 1.00 & 0.379 & 0.346 & 0.321 & 0.238 & 0.532 \\
\hline & Casonas del Norte & & & & 1.00 & $0.603^{*}$ & $0.604^{*}$ & $0.575^{*}$ & $0.591^{*}$ \\
\hline \multirow{4}{*}{$\stackrel{\infty}{\stackrel{\varpi}{\Xi}}$} & Barrancas Sur & & & & & 1.00 & $0.807^{*}$ & $0.923^{*}$ & $0.828^{*}$ \\
\hline & Jardín Claret & & & & & & 1.00 & $0.881^{*}$ & $0.828^{*}$ \\
\hline & Fortín del Pozo & & & & & & & 1.00 & $0.829^{*}$ \\
\hline & La Reserva & & & & & & & & 1.00 \\
\hline
\end{tabular}

"*' 0.05 SIGNIFICANCE

SOURCE: SELF-ELABORATION USING R (R CORE TEAM 2014)

\section{C O N C L U S I O N S}

Economy globalization and production systems transformation, communications technological advances and private mobility facilities have modified territorial / social relationships giving place to socio-territorial segregation. Particularly, in the city of Córdoba, a socio-territorial segregation process shows a considerable amount of gated communities which in many cases have been deployed in advance of the accomplishment of a specific regulatory framework, disregarding land use allocation plans and limiting local government involvement and control. This has led to an urban development process that mainly meets real estate companies' concerns. In this way, urbanization development placement has depended on one-sided decisions based solely on business criteria, overlooking the city's planning and development issues, creating an unreasonable demand for urban infrastructure and service provision expansion. Road network growth promotes the use of the private car while discouraging the adoption of non-motorized modes and precluding the chance of providing a satisfactory transit system, not viable within an increasingly disperse city model. Vasconcellos (2014) deals with the case of Brazilian cities where urban development has followed a similar pattern. This author assigns the 
responsibility of these negative issues to the application of public policies that have tended to favor high income groups.

The article explores trip generation rates in residential land uses in the city of Cordoba, Argentina. This piece of research proofs the initial hypothesis which stated that urban low density residential land uses with little street network connectivity and limited access to transit, encourage a greater use of the private car negatively influencing transit demand and public transport economic sustainability, as well as agglomeration diseconomies as a consequence of higher congestion levels. Results show that car trip generation rates per residential unit in areas with the former characteristics are $300 \%$ higher than rates estimated for denser areas with better access to transit. Furthermore, modal split in this category of locations is concentrated on car use, with more than $70 \%$ of trips by private car. Surprisingly, figures show that in some cases trip generation rates observed in local gated communities surpass values indicated by ITE for urbanizations in the USA.

This rise of car dependence in increasingly larger areas indicates that if this process continues, individual motorized modes trip generation will grow exponentially along with its resulting externalities and urban street congestion increase, damaging specific social groups as well as society as a whole. This urban process entails harmful effects on citizens, mostly affecting those who have no access to a car, because of their income levels, their ages (children and elder) or their capacities. This group, which comprises the greatest portion of urban population, is limited in its access to city assets in terms of education, culture, recreation, health, etc., and is yet exposed to motor vehicle derived externalities such as congestion, air and acoustic pollution and traffic accidents.

The unquestionable relationship between mobility and the built environment, is not often considered regarding decisions that involve land use so that these finally rely on business criteria, leaving aside urban planning issues. However, many other reasons empower this circumstance, such as municipal administration inertia, lack of communication between government areas, intra-institutional isolation and several regulatory gaps. In summary, significant institutional shortcomings are present in local government organization. A serious revision of urban policies and land use regulations but most of all a strong political willpower, are required in order to stop this uncontrolled sprawl of the urban area. The availability of management tools and technical instruments to support urban planning agencies decisions in coordination with mobility managers is essential. This research makes a contribution providing local empirical data required 
to perform traffic impact studies concerning the development of real estate urban projects in order to enable adequate project appraisal for approval with mitigation requirements or their eventual banning. 


\section{REFERE N C I A S B I B L I O G R Á F I C S}

Albrieu, L., Pastor, G., \& Galarraga, J. (2011). Análisis comparativo de viajes a hospitales públicos y privados. Congresso Nacional de Pesquisa e Ensino em Transportes ANPET. Belo Horizonte, Brasil.

Bellotti, M. L. (2006). Urbanizaciones cerradas residenciales: perspectivas de derecho urbanístico y de derecho civil. Córdoba: Advocatus.

Bordese, L, Galarraga J, (2015). Generación de viajes en diferentes tipos de emprendimientos residenciales. XVIII Congresso Nacional de Pesquisa e Ensino em Transportes ANPET. Curitiba, Brasil.

Borsdorf, A., \& Hidalgo, R. (2009). The fragmented city. The Urban Reinventors Online Journal, 1-18.

Brusa J., Lucca C., Riera, A., Taborda, H. , (2013). Movilidad y ambiente construido en la ciudad de Córdoba. XVI Congreso Chileno de Ingeniería de Transporte. Santiago de Chile.

Caggia, M., (2015). Estimación de la pobreza y la indigencia según los datos del Índice Barrial de Precios (IBP) a Diciembre 2014. http://www.cippes.org/cippes-uploads/ archivos/boletin_pobreza_dic_2014-_ok.pdf

Colautti, V. (2013) Procesos de transformación urbana en la ciudad de Córdoba. Seminario Internacional de Investigación en Urbanismo. "V Seminario Internacional de Investigación en Urbanismo, Barcelona-Buenos Aires". Barcelona: DUOT, 2013, p. 480-495.

Dunn, W. N. (2007). Public Policy Analysis: An Introduction (4 edition). Upper Saddle River, N.J.: Pearson.

Galarraga, J., Herz, M., Albrieu, L., Depiante, V., \& Pastor, G. (2007). Característica de los viajes en Hipermercados de la ciudad de Córdoba, Argentina. Congreso Latinoamericano de Transporte Público y Urbano CLATPU. Rio de Janeiro.

Grieco, E., \& Portugal, d. S. (2010). Taxas de geração de viagens em condomínios residenciais. Transportes, 86-94.

Herz, M., Galarraga, J., \& Pastor, G. (2007). Centros universitarios como Polos Generadores de Viajes. Congreso Latinoamericano de Transporte Público y Urbano CLATPU. Rio de Janeiro.

ITE. (2012). Trip Generation Manual. Washington: Intitute of Transportation Engineers.

Marengo, C. (2002). Estrategias habitacionales en los bordes urbanos. Puntos de partida para analizar la expansión suburbana. Revista Proyección.

Marengo, C., \& Elorza, n. (2014). Tendencias de segregación residencial socioeconómica: el caso de Córdoba (Argentina) en el período 2001-2008. EURE, 111-133. 
Observatorio Urbano Córdoba. (2014). Informe Córdoba ciudad (Argentina) 2014. Córdoba: Observatorio Urbano de Córdoba de la Universidad Nacional de Córdoba. http://ouc. unc.edu.ar/investigaciones/

Observatorio de Seguridad Ciudadana - ARGENTINA. (2016). http://www.seguridadciudadana.info/datos-y-estadisticas/homicidios/argentina

Ortúzar, J. y Willumsen L. (2011) Modelling Transport. John Wiley \&Sons.

Peralta, C., \& Liborio, M. (2014). Redistribución poblacional en la ciudad de Córdoba entre los períodos intercensales 1991-2001 / 2001-2008. Evaluación de los procesos de dispersión, densificación, gentrificación y renovación. Revista Vivienda y Ciudad, 99-113.

Portugal, L. d. (2012). Polos geradores de viagens orientados à qualidade de vida e ambiental: modelos e taxas de geração de viagens. Rio de Janeiro, Brasil: Interciência.

PTUMA. (2011). Encuesta origen-destino 2009: Movilidad en el área metropolitana de Córdoba. Córdoba: Proyeto de Transporte Urbano de Buenos Aires.

R Core Team. (2014). R: A language and environment for statistical computing. Vienna, Austria: R Foundation for Statistical Computing. http://www.R-project.org

Riera, A., (2012). Estudio de las Perspectivas del Transporte no Motorizado en Ciudades Argentinas Aplicando Modelos de Generación de Viajes. Tesis de Maestría en Ciencias de la Ingeniería, Mención Transporte. UNC.

Riera A, Brusa, J. (2012) Impacto del ambiente construido sobre los viajes motorizados. XVII Congreso Panamericano de Ingeniería de Tránsito, Transporte y Logística. Santiago de Chile.

Riera, A., Galarraga, J. (2012). Modelos de generación de viajes a pie y en bicicleta en ciudades argentinas, a nivel de hogar. XV Congresso Nacional de Pesquisa e Ensino em Transportes ANPET. Brasil. (http://www.anpet.org.br/ssat/interface/content/autor/ trabalhos/publicacao/2013/57_AC.pdf)

Quintero, Á., Angulo, C., \& Guerrero, J. (2011). Determinación de tasas de generación de viajes para conjuntos residenciales ubicados en la ciudad de Mérida, Venezuela. Ciencia e Ingeniería, 32(1), 45-54.

SECTRA, (2011). http://www.sectra.gob.cl/biblioteca

Tecco, C. (2014). La cuestión de la movilidad urbana en las ciudades contemporáneas: observaciones basadas en el caso de la ciudad de Córdoba. In: C. (. Tecco, Gestión Urbana, Movilidad y Modos de Transporte (pp. 7-15). Córdoba: IIFAP UNC.

United Nations. (2015). World Urbanization Prospects. The 2014 Revision. (ST/ESA/ SER.A/366).

Vasconcellos, E. A. (2013). Políticas de Transporte no Brasil: a Construção da Mobilidade Excludente (1st ed.). Manole, Brasil. 